\title{
A formal synthesis of reserpine: hydrindane approach to the Woodward's ring-E precursor
}

\author{
Goverdhan Mehta * and D. Srinivasa Reddy \\ School of Chemistry, University of Hyderabad, Hyderabad 500 046, India \\ Department of Organic Chemistry, Indian Institute of Science, Bangalore 560 012, India
}

Received (in Cambridge, UK) 17th January 2000, Accepted 2nd March 2000
Published on the Web 11th April 2000

\begin{abstract}
A new synthetic approach to a functionally and stereochemically embellished cyclohexanoid, corresponding to the Woodward's ring-E intermediate $\mathbf{2 4}$ of the complex indole alkaloid reserpine $\mathbf{1}$ is delineated. Our scheme emanates from a readily available endo-tricyclo[5.2.1.0 $\left.0^{2,6}\right]$ decane system from which cis-hydrindane and cyclohexanoid moieties are sequentially extracted. The strategy outlined here exploits the propensity of the endo-tricyclo[5.2.1.0 $\left.0^{2,6}\right]$ decane and cis-hydrindane systems to react from the convex face to generate the requisite stereochemical pattern. Since $\mathbf{2 4}$ has been previously elaborated to the natural product, the present effort constitutes a formal synthesis of rac-reserpine.
\end{abstract}

The pentacyclic indole alkaloid reserpine 1, first isolated from the Indian snake root, Rauwolfia serpentina Benth, occupies a historically important position among natural products for a variety of reasons. ${ }^{1,2}$ Besides having a complex structure, $\mathbf{1}^{2}$ was among the very first few natural products to have been used clinically. For quite some time, reserpine 1 was commonly employed for the treatment of hypertension and mental disorders. The pentacyclic framework of reserpine 1 with six stereogenic centres and ample functionalisation was considered as a major synthetic challenge in the 1950's and 1960's. Its first synthesis by Woodward, ${ }^{3 a}$ nearly forty years ago, was a landmark and ranks among the classics of modern organic synthesis. Over the years, reserpine has continued to sustain the interest and attention of synthetic chemists ${ }^{3,4}$ and as many as eight total syntheses have been recorded to date ${ }^{3 a-h}$ The approaches adopted towards the successful syntheses of $\mathbf{1}$ fall into two broad categories. In the first group are the approaches that focus on the construction of ring $E$ of reserpine wherein five of the six stereogenic centres and much of the functionality reside. The original Woodward approach ${ }^{3 a}$ and those of Pearlman, ${ }^{3 b}$ Stork, ${ }^{3 e}$ Fraser-Reid, ${ }^{3 f}$ Liao ${ }^{3 g}$ and Hanessian ${ }^{3 h}$ have targeted an appropriately functionalised ring-E precursor $\mathbf{2}$ in which the requisite stereochemistry is built in. Woodward ${ }^{3 a}$ employed the Diels-Alder adduct of vinylacrylic acid and benzoquinone as the starting material in which a series of clever functional group manipulations were orchestrated to attain the ring-E stereo- chemistry. Intramolecular $[2+2]$ photocycloaddition in a cyclohexene derivative and cyclobutane fragmentation was the stratagem employed by Pearlman ${ }^{3 b}$ in accessing ring $\mathrm{E}$ of $\mathbf{1}$. Stork et al. ${ }^{3 e}$ and Liao et al. ${ }^{3 g}$ employed the bicyclo[2.2.2]octane scaffold to deliver the desired stereochemistry of ring E. FraserReid $^{3 f}$ and Hanessian ${ }^{3 h}$ employed glucose and quinic acid, respectively, as chirons in their approach to reserpine $\mathbf{1}$.

On the other hand, Wender et al. ${ }^{3 c}$ and Martin et al. ${ }^{3 d}$ in their successful synthesis of reserpine have focused on assembling a cis-hydroisoquinoline moiety $\mathbf{3}$, incorporating the DE-rings of the natural product, employing Diels-Alder/Cope rearrangement and intramolecular Diels-Alder reaction as the key steps, respectively. In both, the E-ring as well as DE-ring approaches, appropriately constructed precursors $\mathbf{2}$ and $\mathbf{3}$ are condensed with indole derived AB-ring partners $\mathbf{4}$ and $\mathbf{5}$, respectively, to generate the pentacyclic framework of reserpine 1, Scheme 1 .

Several innovative and interesting solutions to ring-E construction have been presented en route to the synthesis of 1 . We have conceptualised a new approach to Woodward's ring-E precursor of reserpine 1 from readily accessible endo-tricyclo$\left[5.2 .1 .0^{2,6}\right]$ decane derivative $6^{5}$ The key feature of this strategy is the retrieval of the six-membered ring (see bold portion in $\mathbf{6}$ ) embedded within the tricyclic frame of $\mathbf{6}$. Another distinctive aspect of this approach is that all the ten carbon atoms of Woodward's ring-E intermediate (see 8) are present in the tricyclic framework $\mathbf{6}$, which in turn is assembled from two $\mathrm{C}_{5}$

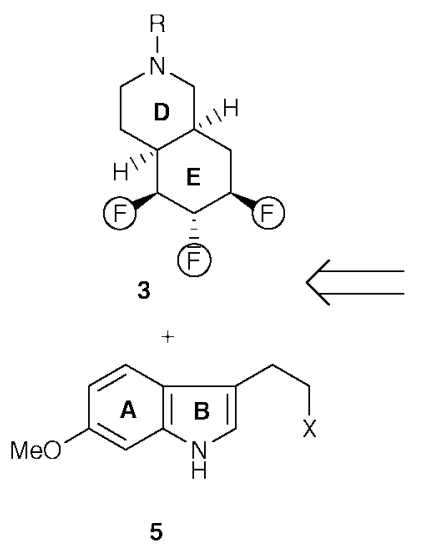

5

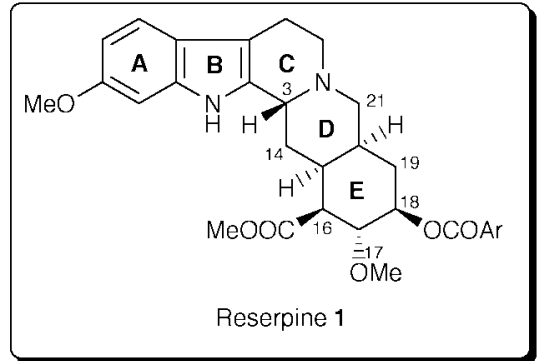

Scheme 1

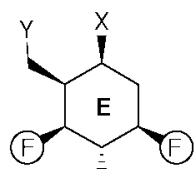

(F)

2

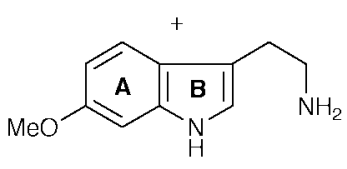

4 
cyclopentadiene units (vide infra). Thus, no carbon needs to be added or removed from the tricyclic precursor $\mathbf{6}$, only skeletal restructuring and functional group changes are required. In practical terms, elaboration of $\mathbf{6}$ to $\mathbf{8}$ requires opening-up of the bridge $(6 \rightarrow 7)$, functional group adjustment as called for and finally oxidative cleavage of the double bond in 7 to deliver the ring-E intermediate 8 . A particularly attractive feature of our simple approach is that both endo-tricyclic system $\mathbf{6}$ and the cishydrindane 7 are amenable to stereochemical control through their skeletal topology, with reagent addition expected to occur only from the exo/convex face of the molecule. We report here the successful execution of the approach towards Woodward's ring-E intermediate 9 as shown in Scheme 2, which in a formal sense constitutes a new synthesis of rac-reserpine $\mathbf{1}$.

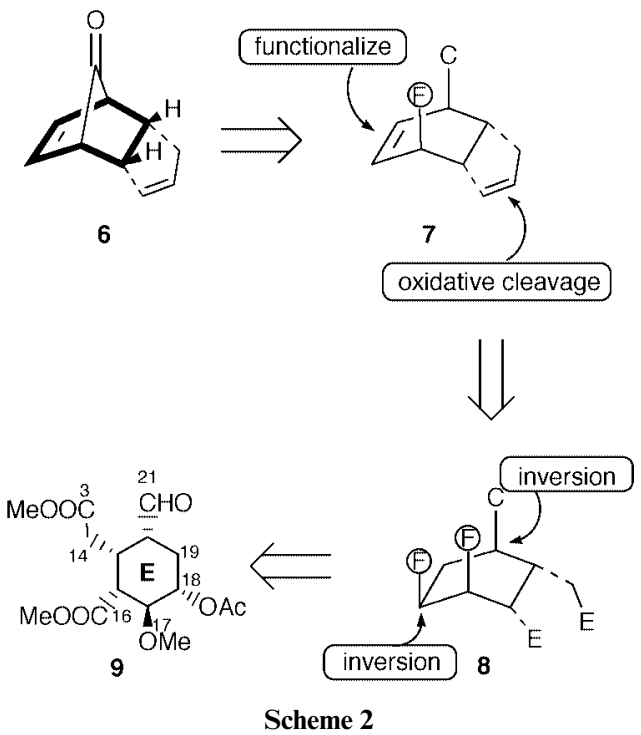

Our approach emanated from two abundantly available $\mathrm{C}_{5}$ building blocks, cyclopentadiene and 5,5-dimethoxytetrachlorocyclopentadiene 10, which readily enter into Diels-Alder reaction to furnish the known tricyclic endo-adduct $11 .{ }^{6}$ The first priority was to protect the distal disubstituted cyclopentene double bond in a manner that at an appropriate stage it could be oxidatively cleaved to generate the cis disposed substituents at $\mathrm{C} 15$ and $\mathrm{C} 16$ (reserpine numbering) on the E-ring of $\mathbf{1}$. Regioselective, catalytic cis-dihydroxylation of $\mathbf{1 1}$ led to the tricyclic exo,exo-diol $\mathbf{1 2}$ which was directly subjected to exhaustive reductive dehalogenation in metal-ammonia solution to furnish 13. Exposure of $\mathbf{1 3}$ to acetone in the presence of Amberlyst-15 resulted in the two desired protectiondeprotection events taking place in a single-pot reaction. While the cis-diol moiety was protected as the acetonide derivative, the dimethyl acetal was deprotected to give keto-acetonide 14. Scheme 3. The stage was now set for the removal of the carbonyl bearing bridge in $\mathbf{1 4}$ to unravel the hydrindane framework. This was accomplished via Baeyer-Villiger (BV) oxidation. Reaction of $\mathbf{1 4}$ with $m$-chloroperbenzoic acid and methanolysis of the resulting lactones led to the formation of regioisomeric hydroxy esters $\mathbf{1 5}$ and $\mathbf{1 6}$ in a 55:45 ratio, Scheme 3. Apparently, the distal acetonide group in $\mathbf{1 4}$ has very little effect on the regiochemistry of BV oxidation and nearly equal amounts of $\mathbf{1 5}$ and $\mathbf{1 6}$ are obtained. The two esters $\mathbf{1 5}$ and $\mathbf{1 6}$ are readily separable and could be distinguished through an incisive analysis of their ${ }^{1} \mathrm{H}-{ }^{1} \mathrm{H}$ COSY spectra derived connectivities as depicted in Fig. 1. Although the lack of BV oxidation regioselectivity in $\mathbf{1 4}$ was a somewhat unsatisfactory outcome, the redeeming feature was the desired migration of the olefinic bond into conjugation with the ester moieties in $\mathbf{1 5}$ and $\mathbf{1 6}$ during methanolysis. This was considered necessary to recreate the correct stereochemistry at the ester bearing carbon

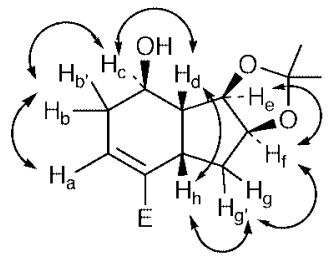

15

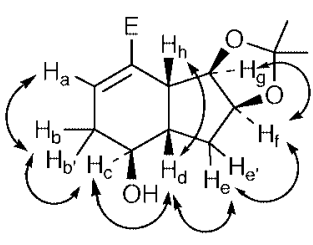

16
Fig. 1

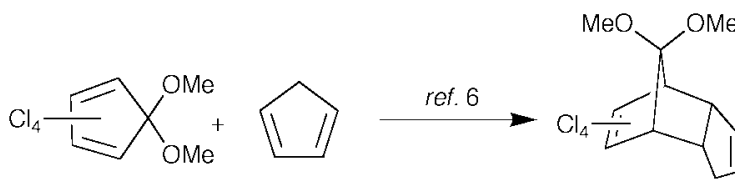

10

11

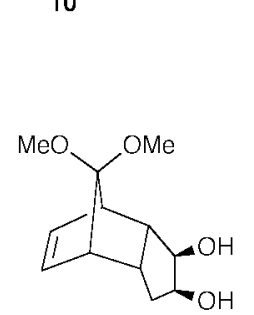

$\downarrow$
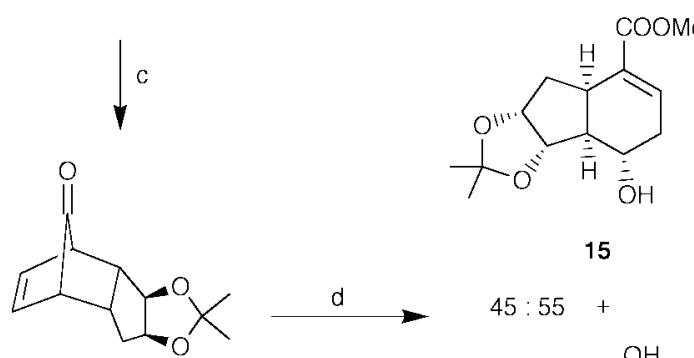

15

$45: 55+$

14

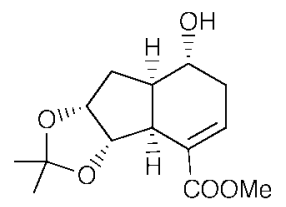

16

Scheme 3 Reagents and conditions: (a) $\mathrm{OsO}_{4}, \mathrm{Me}_{2} \mathrm{CO}-\mathrm{H}_{2} \mathrm{O}-t-\mathrm{BuOH}$ $(5: 3: 1), 24 \mathrm{~h}, 90 \%$; (b) $\mathrm{Na}-\mathrm{NH}_{3}$, THF, EtOH, $15 \mathrm{~min}, 50 \%$; (c) $\mathrm{Me}_{2} \mathrm{CO}-$ Amberlyst-15, 6 h, 83\%; (d) MCPBA, DCM, 30 min; KOH, $\mathrm{MeOH}, 20 \mathrm{~min}, 63 \%$.

centre (C20 of reserpine), taking advantage of the topology of the $c i s$-hydrindane framework.

The free hydroxy group in the required regioisomer $\mathbf{1 5}$ was methylated employing methyl iodide and solid $\mathrm{KOH}$ under solvent free conditions ${ }^{7}$ to furnish the methoxy ester 17. It was now proposed to functionalise the allylic position in the ester $\mathbf{1 7}$ to generate the $\mathrm{C} 18$ centre of reserpine 1 present in ring $\mathrm{E}$. Several reagents like $\mathrm{Cr}(\mathrm{CO})_{6}-t-\mathrm{BuOOH},{ }^{8 a} \mathrm{CrO}_{3}$-dimethylpyrazole, ${ }^{8 b} \mathrm{CrO}_{3}-\mathrm{AcOH},{ }^{8 c} \mathrm{SeO}_{2}$ (cat)- $t$ - $\mathrm{BuOOH}^{8 d}$ etc. were tried to oxidise 17 to the $\alpha, \beta$-unsaturated enone 18 but none of them proved to be entirely satisfactory. Best results were obtained with PDC on Celite in the presence of tert-butyl hydroperoxide and $\mathbf{1 8}$ was obtained in $\sim 30 \%$ yield, ${ }^{8 e}$ Scheme 4 . Luche reduction ${ }^{9}$ of the enone carbonyl in 18 proceeded stereoselectively in an expected fashion to furnish 19 . The hydride addition to the carbonyl group in $\mathbf{1 8}$ was from the convex face of the cis-hydrindane moiety and the correct stereochemistry corresponding to the $\mathrm{C}_{18}$ centre of reserpine was established. The next key step was to set the stereochemistry of the methoxycarbonyl bearing centre and towards that end the double bond in 19 was subjected to catalytic hydrogenation. The reduction was fairly stereoselective and an $85: 15$ mixture of epi- 

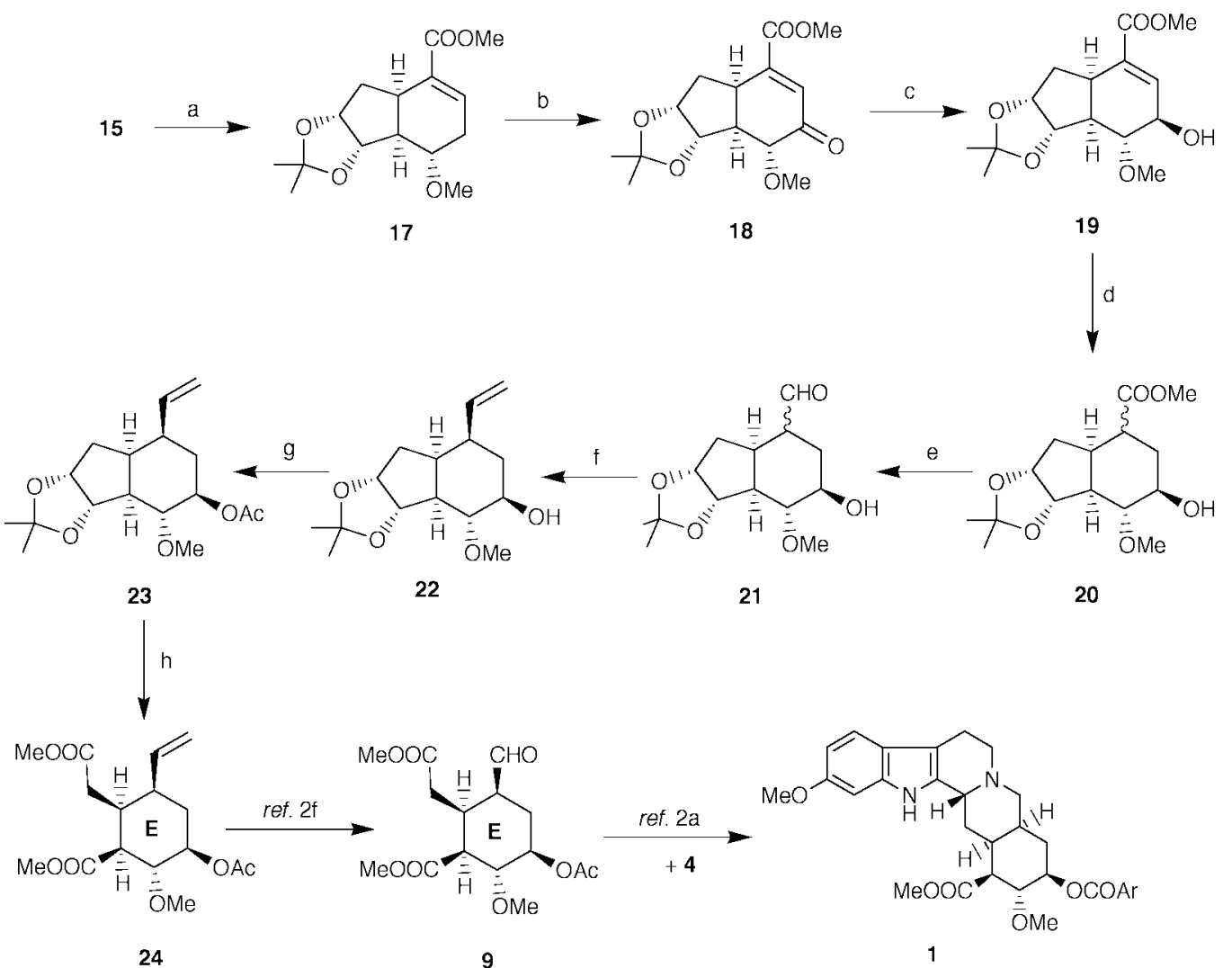

24

Scheme 4 Reagents and conditions: (a) $\mathrm{KOH}, \mathrm{MeI}, 20 \mathrm{~h}, 90 \%$; (b) $\mathrm{PDC}, t$-BuOOH, Celite, benzene, 1 h, 30\%; (c) $\mathrm{NaBH}_{4}, \mathrm{CeCl}_{3} \cdot 7 \mathrm{H}_{2} \mathrm{O}, \mathrm{MeOH}$, $-20{ }^{\circ} \mathrm{C}, 15 \mathrm{~min}, 62 \%$; (d) $\mathrm{H}_{2}, \mathrm{PtO}_{2}$, EtOH, $1 \mathrm{~h}$; (e) DIBAL-H, DCM, $-78{ }^{\circ} \mathrm{C}, 30 \mathrm{~min}$; (f) $\mathrm{MePPh}_{3}{ }^{+} \mathrm{I}^{-}, n$-BuLi, 15 min, $48 \%$ (for 3 steps); (g) Ac $\mathrm{O}_{2}$, pyridine, DMAP, 2 h, $86 \%$; (h) $30 \%$ TFA, 1 h; $\mathrm{NaIO}_{4}, 10 \%$ aq. THF, $15 \mathrm{~min}$; Jones oxidation, $\mathrm{Me}_{2} \mathrm{CO}_{2} \mathrm{CH}_{2} \mathrm{~N}_{2}$, ether, $21 \%$ (for 4 steps).

mers 20 was obtained. The major epimer formed during the reduction of 19 was the $\alpha$-isomer with endo-methoxycarbonyl group corresponding to the required C20-stereochemistry in $\mathbf{1}$. The separation of epimers 20 proved difficult at this stage and therefore we proceeded further as such towards the Woodward's intermediate. DIBAL-H reduction of $\mathbf{2 0}$ to the aldehyde $\mathbf{2 1}$ and Wittig olefination furnished 22. The Wittig olefination was necessitated by our intent to protect the aldehyde functionality in $\mathbf{2 1}$ during subsequent steps. It was reasoned that the aldehyde functionality, which is present in the target structure could be readily regenerated at an appropriate stage from the olefin. As $\mathbf{2 2}$ turned out to be a nice solid, crystallization led to ready purification and it was obtained as a single stereoisomer and fully characterized. The secondary hydroxy group in $\mathbf{2 2}$ was now acetylated to $\mathbf{2 3}$. The final manoeuvre now was the unraveling of the cis disposed methoxycarbonyl and acetic acid side arms on the E-ring, corresponding to $\mathrm{C} 16$ and $\mathrm{C} 15$ of reserpine, respectively, from the five membered ring of the cis-hydrindane 23. A four step sequence consisting of acetonide deprotection, periodate cleavage of the resultant diol to dialdehyde, Jones oxidation to the dicarboxylic acid and diazomethane esterification led to the diester $\mathbf{2 4}$ in modest yield, Scheme 4. The diester $\mathbf{2 4}$ has been recently reported by Fraser-Reid et al. ${ }^{3 \mathrm{f}}$ and our synthetic sample was found to be identical with their sample in all respects. On ozonolysis, the olefinic moiety in $\mathbf{2 4}$ is readily transformed to the aldehyde functionality and the resulting product is the Woodward's reserpine precursor $9,{ }^{3 f}$ which has been earlier elaborated to the natural product. ${ }^{3 a}$

In short, we have outlined a new approach to a densely functionalised cyclohexanoid, identical with Woodward's ring-E intermediate from readily available cyclopentadiene based building-blocks. Our approach, notable for its conceptual simplicity, relies on the topology of the endo-tricyclo$\left[5.2 .1 .0^{2,6}\right]$ decane and $c i$-hydrindane ring systems to achieve the desired stereoselectivity.

\section{Experimental}

\section{General}

Melting points were recorded on a Büchi SMP-20 apparatus and are uncorrected. Infrared spectra were recorded on PerkinElmer model 1310 or JASCO FT-IR. Solid samples were recorded as $\mathrm{KBr}$ pellets and liquids as thin films. ${ }^{1} \mathrm{H}$ NMR spectra were recorded at $200 \mathrm{MHz}$ or $300 \mathrm{MHz}$ and ${ }^{13} \mathrm{C}$ NMR spectra were recorded at $50 \mathrm{MHz}$ or $75 \mathrm{MHz}$ on Bruker AC 200 or JNM $\lambda-300$ spectrometers respectively. ${ }^{1} \mathrm{H}$ and ${ }^{13} \mathrm{C}$ NMR samples were made in $\mathrm{CDCl}_{3}$ solvent and chemical shifts are reported on the $\delta$ scale using tetramethylsilane $\left(\mathrm{Me}_{4} \mathrm{Si}\right)$ as the internal standard. $J$ values are given in $\mathrm{Hz}$. The standard abbreviations br, s, d, t, q and $\mathrm{m}$ refer to broad, singlet, doublet, triplet, quartet and multiplet, respectively. Mass spectra measurements were carried out on a JEOL JMS DX-303 spectrometer. Elemental analyses were carried out using a Perkin-Elmer 240C elemental analyzer or Carlo Erba 1106$\mathrm{CHN}$ analyzer. Analytical thin-layer chromatography (TLC) was performed on $(10 \times 5 \mathrm{~cm})$ glass plates coated with Acme's silica gel G (containing 13\% calcium sulfate as binder). Column chromatography was performed using Acme's silica gel (100-200 mesh) and ethyl acetate-hexane was used as eluent. Moisture sensitive reactions were performed using standard syringe-septum techniques under a nitrogen atmosphere. All solvents were distilled over appropriate drying agents, prior to use. Yields reported are isolated yields of materials judged homogeneous by TLC and NMR.

\section{1,7,8,9-Tetrachloro-10,10-dimethoxytricyclo[5.2.1.0 $\left.{ }^{2,6}\right] \mathrm{dec}-8$ - ene-3,4-diol 12}

Osmium tetroxide ( $115 \mathrm{mg}, 0.45 \mathrm{mmol}, 0.5 \mathrm{~mol} \%$ ) was added to a stirred solution of adduct 11 (30 g, $90 \mathrm{mmol})$, prepared from tetrachlorodimethoxycyclopentadiene $\mathbf{1 0}$ and cyclopentadiene by following the literature procedure, ${ }^{5}$ NMO (16 g, 136 
$\mathrm{mmol})$ in acetone $(100 \mathrm{ml})$, water $(100 \mathrm{ml})$ and $t$-BuOH $(20 \mathrm{ml})$ at room temperature $\left(25^{\circ} \mathrm{C}\right)$ with stirring. The reaction was slightly exothermic initially and was maintained at room temperature with a water bath. After stirring for $24 \mathrm{~h}$, the osmate ester was hydrolyzed with a saturated solution of $\mathrm{NaHSO}_{3}$ and extracted with EtOAc several times. The combined organic layer was washed with water, brine and dried. The residue obtained after the removal of the solvent was passed through a small silica gel column to furnish diol $12(\sim 29 \mathrm{~g})$ in $88 \%$ yield as a white solid and was recrystallized from DCM-hexane. Mp: $111{ }^{\circ} \mathrm{C}$; IR (KBr): $v_{\max } 3362,1604,1450,1192 \mathrm{~cm}^{-1} ;{ }^{1} \mathrm{H}$ NMR (200 MHz, $\left.\mathrm{CDCl}_{3}\right): \delta 4.00-3.80(\mathrm{~m}, 2 \mathrm{H}), 3.59(\mathrm{~s}, 3 \mathrm{H}), 3.54(\mathrm{~s}$, $3 \mathrm{H}), 3.42-3.31(\mathrm{~m}, 1 \mathrm{H}), 3.06(\mathrm{dd}, 1 \mathrm{H}, J=9.5,4.3), 2.4(\mathrm{br} \mathrm{s}$ $2 \mathrm{H}), 1.89(\mathrm{dd}, 1 \mathrm{H}, J=12.8,8.8,5), 1.68-1.50(\mathrm{~m}, 1 \mathrm{H}) ;{ }^{13} \mathrm{C}$ NMR (50 MHz, $\left.\mathrm{CDCl}_{3}\right): \delta 130.1,129.4,114.8,76.4,74.8,72.9$, 58.9 (2C), 52.5, 51.6, 51.4, 30.6; m/z (EI): $328\left(\mathrm{M}^{+}-\mathrm{Cl}\right)$ Found: C, 39.55; $\mathrm{H}, 3.81 . \mathrm{C}_{12} \mathrm{H}_{14} \mathrm{O}_{4} \mathrm{Cl}_{4}$ requires: $\mathrm{C}, 39.59 ; \mathrm{H}$, $3.88 \%$.

\section{0,10-Dimethoxytricyclo[5.2.1.0 $\left.{ }^{2,6}\right]$ dec-8-ene-3,4-diol 13}

In a 11 three necked round bottomed flask fitted with a condenser, $\mathrm{KOH}$ guard tube and a septum, $600 \mathrm{ml}$ of distilled liquid ammonia was taken and a solution of diol 12 (18.2 g, 50 mmol) in $80 \mathrm{ml}$ dry THF and $8 \mathrm{ml}$ of dry ethanol were added. Small pieces of freshly cut sodium were slowly added to the reaction mixture with stirring till the blue color persisted. The reaction mixture was stirred for another 15 minutes and $\sim 5 \mathrm{~g}$ of solid $\mathrm{NH}_{4} \mathrm{Cl}$ were added. Ammonia was allowed to evaporate and the residue was diluted with water. Extraction with ethyl acetate, washing with brine and removal of solvent afforded a viscous liquid which was distilled at $165^{\circ} \mathrm{C} / 1$ Torr to furnish pure diol $13(6.9 \mathrm{~g})$ in 45\% yield. IR (neat): $v_{\max } 3406,3061$, $1440,1273 \mathrm{~cm}^{-1} ;{ }^{1} \mathrm{H}$ NMR $\left(200 \mathrm{MHz}, \mathrm{CDCl}_{3}\right): \delta 6.19-6.17(\mathrm{~m}$, $2 \mathrm{H}), 4.00(\mathrm{~m}, 1 \mathrm{H}), 3.52(\mathrm{t}, 1 \mathrm{H}, J=5), 3.28(\mathrm{~s}, 3 \mathrm{H}), 3.12(\mathrm{~s}, 3 \mathrm{H})$, 3.05-2.60 (series of $\mathrm{m}, 4 \mathrm{H}), 1.82-1.70(\mathrm{~m}, 1 \mathrm{H}), 1.22-1.10(\mathrm{~m}$, $1 \mathrm{H}) ;{ }^{13} \mathrm{C}$ NMR $\left(50 \mathrm{MHz}, \mathrm{CDCl}_{3}\right): \delta 134.2,133.6,122.3,77.4$, 75.9, 51.8, 49.9 (2C), 48.3, 46.8, 42.0, 33.7; $\mathrm{m} / \mathrm{z}(\mathrm{EI}): 226\left(\mathrm{M}^{+}\right)$; Found: C, 63.75; H, 8.05. $\mathrm{C}_{12} \mathrm{H}_{18} \mathrm{O}_{5}$ requires: $\mathrm{C}, 63.60 ; \mathrm{H}$, $8.02 \%$.

\section{5,5-Dimethyl-4,6-dioxatetracyclo[8.2.1.0 $\left.0^{2,9}, 0^{3,7}\right]$ tridec-11-en-13- one 14}

To a solution of diol $\mathbf{1 3}$ (8 g, $35.4 \mathrm{mmol})$ in acetone $(25 \mathrm{ml})$, Amberlyst-15 catalyst was added and the resulting heterogeneous mixture was stirred at $\mathrm{rt}$ for $6 \mathrm{~h}$. Filtration of the resin and concentration furnished the keto-acetonide $14(6.1 \mathrm{~g})$ in $83 \%$ yield as a colorless solid. Mp: $74{ }^{\circ} \mathrm{C}$; IR $(\mathrm{KBr}): v_{\max } 1778$, $1373,1062,719 \mathrm{~cm}^{-1} ;{ }^{1} \mathrm{H}$ NMR $\left(200 \mathrm{MHz}, \mathrm{CDCl}_{3}\right): \delta 6.54-6.51$ $(\mathrm{m}, 2 \mathrm{H}), 4.39(\mathrm{~m}, 1 \mathrm{H}), 4.17(\mathrm{~m}, 1 \mathrm{H}), 3.30-2.70$ (series of $\mathrm{m}$, $4 \mathrm{H}), 2.20-2.00(\mathrm{~m}, 1 \mathrm{H}), 1.60-1.55(\mathrm{~m}, 1 \mathrm{H}), 1.47(\mathrm{~s}, 3 \mathrm{H}), 1.26(\mathrm{~s}$, $3 \mathrm{H}) ;{ }^{13} \mathrm{C}$ NMR $\left(50 \mathrm{MHz}, \mathrm{CDCl}_{3}\right): \delta 202.2,133.0,132.0,110.8$, 84.3, 83.4, 52.0, 50.2, 48.5, 42.2, 35.0, 27.9, 25.4; $\mathrm{m} / \mathrm{z}$ (EI): $207\left(\mathrm{M}^{+}-1\right)$; Found: $\mathrm{C}, 70.62 ; \mathrm{H}, 7.34 . \mathrm{C}_{13} \mathrm{H}_{16} \mathrm{O}_{3}$ requires: C, $70.89 ; \mathrm{H}, 7.32 \%$.

\section{Methyl 4-hydroxy-2,2-dimethyl-3b,4,5,7a,8,8a-hexahydro- $3 \mathrm{a} H$-indeno $[1,2-d][1,3]$ dioxole-7-carboxylate 15 and methyl 7-hydroxy-2,2-dimethyl-3b,6,7,7a,8,8a-hexahydro-3aH-indeno- $[1,2-d][1,3]$ dioxole-4-carboxylate 16}

To an ice-cooled solution of the tricyclic ketone $\mathbf{1 4}$ (4.4 g, 20 mmol) and anhydrous $\mathrm{Na}_{2} \mathrm{CO}_{3}(2.2 \mathrm{~g}, 20.6 \mathrm{mmol}$ in dry dichloromethane $(50 \mathrm{ml}) \mathrm{m}$-chloroperbenzoic acid $(5.4 \mathrm{~g}, 70 \%$, $22 \mathrm{mmol}$ ) was added and the reaction mixture was stirred for $30 \mathrm{~min}$. The reaction was quenched with saturated aq. $\mathrm{NaHCO}_{3}$ and the contents were stirred for another $15 \mathrm{~min}$. The organic layer was separated and the aqueous layer was further extracted with dichloromethane. The combined organic extracts were again washed with saturated aq. $\mathrm{NaHCO}_{3}$, followed by brine.
The crude mixture of the lactones $(\sim 4.8 \mathrm{~g})$ obtained after the removal of solvent was dissolved in dry methanol $(15 \mathrm{ml})$ and a small pellet of $\mathrm{KOH}$ was added. The contents were then stirred for $20 \mathrm{~min}$ at room temperature. After the removal of the methanol under vacuum, the residue was diluted with water and extracted with diethyl ether. The ethereal layer was washed with water and dried. The crude residue obtained after the removal of the solvent was loaded on the silica gel column and eluted with $20 \%$ ethyl acetate-hexane to furnish the hydroxy esters $\mathbf{1 5}(1.85 \mathrm{~g})$ and $\mathbf{1 6}(1.62 \mathrm{~g})$ in $63 \%$ overall yield in $55: 45$ ratio.

15: IR: $v_{\max } 3445,1714,1647,1379,1209,750 \mathrm{~cm}^{-1} ;{ }^{1} \mathrm{H}$ NMR $\left(200 \mathrm{MHz}, \mathrm{CDCl}_{3}\right): \delta 6.84(\mathrm{~m}, 1 \mathrm{H}), 4.85(\mathrm{~d}, 1 \mathrm{H}, J=5.6), 4.70$ $(\mathrm{t}, 1 \mathrm{H}, J=5.2), 3.74(\mathrm{~s}, 3 \mathrm{H}), 3.60-3.20(\mathrm{~m}, 2 \mathrm{H}), 2.64(\mathrm{dt}, 1 \mathrm{H}$, $J=18.4,5.8), 2.42(\mathrm{dd}, 1 \mathrm{H}, J=14,6.6), 2.16(\mathrm{~m}, 1 \mathrm{H}), 2.02(\mathrm{dd}$, $1 \mathrm{H}, J=11.4,6.6), 1.48(\mathrm{~s}, 3 \mathrm{H}), 1.32(\mathrm{~m}, 1 \mathrm{H}), 1.31(\mathrm{~s}, 3 \mathrm{H})$; ${ }^{13} \mathrm{C}$ NMR $\left(50 \mathrm{MHz}, \mathrm{CDCl}_{3}\right): \delta 166.9,136.4,132.5,109.4,89.9$, 79.9, 64.4, 52.1, 51.6, 39.3, 37.2, 35.4, 26.3, 23.9; Found: C, 62.63; $\mathrm{H}, 7.53 . \mathrm{C}_{14} \mathrm{H}_{20} \mathrm{O}_{5}$ requires $\mathrm{C}, 62.67 ; \mathrm{H}, 7.51 \%$.

16: IR: $v_{\max } 3439,1714,1647,1259,1209,748 \mathrm{~cm}^{-1} ;{ }^{1} \mathrm{H}$ NMR $\left(200 \mathrm{MHz}, \mathrm{CDCl}_{3}\right): \delta 6.87(\mathrm{~m}, 1 \mathrm{H}), 4.87(\mathrm{~m}, 2 \mathrm{H}), 4.05(\mathrm{~m}, 1 \mathrm{H})$, $3.78(\mathrm{~s}, 3 \mathrm{H}), 3.05(\mathrm{~m}, 1 \mathrm{H}), 2.80(\mathrm{~m}, 1 \mathrm{H}), 2.39(\mathrm{~m}, 2 \mathrm{H}), 1.92(\mathrm{dd}$, $1 \mathrm{H}, J=13.6,5.8), 1.49(\mathrm{~s}, 3 \mathrm{H}), 1.35(\mathrm{~m}, 1 \mathrm{H}), 1.30(\mathrm{~s}, 3 \mathrm{H})$; ${ }^{13} \mathrm{C}$ NMR $\left(50 \mathrm{MHz}, \mathrm{CDCl}_{3}\right): \delta 167.1,136.4,129.3,109.8,84.7$, 79.0, 65.3, 51.7, 42.6, 41.0, 34.5, 30.3, 26.4, 24.1; $\mathrm{m} / \mathrm{z}$ (EI): 253 $\left(\mathrm{M}^{+}-15\right)$.

\section{Methyl 4-methoxy-2,2-dimethyl-3b,4,5,7a,8,8a-hexahydro-3a $H$ -} indeno[1,2- $d][1,3]$ dioxole-7-carboxylate 17

A mixture of 15 (1.5 g, $5.6 \mathrm{mmol})$, methyl iodide (2.6 ml, 40 $\mathrm{mmol})$ and $\mathrm{KOH}(\sim 360 \mathrm{mg}, 6 \mathrm{mmol})$ was stirred at $\mathrm{rt}$ for $20 \mathrm{~h}$ and then loaded on a pad of silica gel and eluted with $10 \%$ EtOAc-hexane to afford $17(1.41 \mathrm{~g})$ in $90 \%$ yield. IR: $v_{\max } 1712$, 1649, 1437, 1379, 1248, $750 \mathrm{~cm}^{-1}$; ${ }^{1} \mathrm{H}$ NMR $\left(200 \mathrm{MHz}, \mathrm{CDCl}_{3}\right)$ : $\delta 6.90(\mathrm{~m}, 1 \mathrm{H}), 4.80-4.60(\mathrm{~m}, 2 \mathrm{H}), 4.05(\mathrm{~m}, 1 \mathrm{H}), 3.75(\mathrm{~s}, 3 \mathrm{H})$, $3.38(\mathrm{~s}, 3 \mathrm{H}), 3.10-2.90(\mathrm{~m}, 1 \mathrm{H}), 2.75(\mathrm{dt}, 1 \mathrm{H}, J=18.4,5.8), 2.47$ (dd, $1 \mathrm{H}, J=17.5,6), 2.10-2.00(\mathrm{~m}, 2 \mathrm{H}), 1.48(\mathrm{~s}, 3 \mathrm{H}), 1.36(\mathrm{~m}$, 1H), $1.32(\mathrm{~s}, 3 \mathrm{H}) ;{ }^{13} \mathrm{C} \mathrm{NMR}\left(50 \mathrm{MHz}, \mathrm{CDCl}_{3}\right): \delta 167.0,136.2$, $132.5,109.3,82.2,79.9,72.7,56.2,51.6,49.8,39.4,36.9,30.6$, 26.3, 24.0; $\mathrm{m} / \mathrm{z}(\mathrm{EI}): 282\left(\mathrm{M}^{+}\right)$; Found: C, 63.85; H, 7.87. $\mathrm{C}_{15} \mathrm{H}_{22} \mathrm{O}_{5}$ requires: $\mathrm{C}, 63.81 ; \mathrm{H}, 7.85 \%$.

\section{Methyl 4-methoxy-2,2-dimethyl-5-oxo-3b,4,5,7a,8,8a-hexa- hydro-3a $H$-indeno[1,2- $d][1,3]$ dioxole-7-carboxylate 18}

To an ice-cooled solution of $\mathbf{1 7}(1.2 \mathrm{~g}, 4.25 \mathrm{mmol})$ in benzene $(15 \mathrm{ml})$ was added Celite $(200 \mathrm{mg})$, PDC $(3.16 \mathrm{~g}, 8.5 \mathrm{mmol})$ and $0.4 \mathrm{ml}$ of $80 \%$ tert-butyl hydroperoxide. The reaction mixture was stirred at $\mathrm{rt}$ for $1 \mathrm{~h}$ and then filtered through a small Celite pad. The crude product obtained after evaporation of the solvent was loaded on a silica gel column and eluted with $10 \%$ EtOAc-hexane to furnish enone $18(230 \mathrm{mg})$ and unreacted starting material $(450 \mathrm{mg}$ ) in $30 \%$ yield (on the basis of recovery of starting material). IR: $v_{\max } 1724,1701,1439,1253,1209,756$ $\mathrm{cm}^{-1} ;{ }^{1} \mathrm{H}$ NMR $\left(200 \mathrm{MHz}, \mathrm{CDCl}_{3}\right): \delta 6.71(\mathrm{~s}, 1 \mathrm{H}), 4.86(\mathrm{t}, 1 \mathrm{H}$, $J=5.4), 4.69$ (d, $1 \mathrm{H}, J=5.6), 3.85$ (s, 3H), $3.61(\mathrm{~s}, 3 \mathrm{H}), 3.59-$ $3.50(\mathrm{~m}, 2 \mathrm{H}), 2.70-2.48(\mathrm{~m}, 2 \mathrm{H}), 1.85-1.75(\mathrm{~m}, 1 \mathrm{H}), 1.49(\mathrm{~s}$, $3 \mathrm{H}), 1.33$ (s, 3H); ${ }^{13} \mathrm{C} \mathrm{NMR}\left(50 \mathrm{MHz}, \mathrm{CDCl}_{3}\right): \delta 198.5,165.9$, 148.2, 131.7, 109.7, 82.2, 80.5, 78.6, 59.5, 52.7, 51.4, 37.7, 37.3, 26.2, 23.8; $\mathrm{m} / \mathrm{z}$ (EI): $296\left(\mathrm{M}^{+}+1\right)$; Found: C, 60.62; H, 6.83 . $\mathrm{C}_{15} \mathrm{H}_{22} \mathrm{O}_{5}$ requires: $\mathrm{C}, 60.80 ; \mathrm{H}, 6.80 \%$.

Methyl 5-hydroxy-4-methoxy-2,2-dimethyl-3b,4,5,7a,8,8a-hexahydro-3a $H$-indeno[1,2- $d][1,3]$ dioxole-7-carboxylate 19

To a solution of enone 18 (220 mg, $0.74 \mathrm{mmol})$ and $\mathrm{CeCl}_{3} \cdot 7 \mathrm{H}_{2} \mathrm{O}(335 \mathrm{mg}, 0.9 \mathrm{mmol})$ in dry methanol $(5 \mathrm{ml})$ was added $\mathrm{NaBH}_{4}(35 \mathrm{mg}, 0.9 \mathrm{mmol})$ at $-20{ }^{\circ} \mathrm{C}$ and the mixture was stirred for $15 \mathrm{~min}$ at the same temperature. Methanol was removed under reduced pressure and the residue obtained was 
dissolved in water and extracted with ethyl acetate. The organic extract was washed, dried and evaporated to furnish allylic alcohol $19(138 \mathrm{mg})$ in $62 \%$ yield. IR: $v_{\max } 3460,1715,1440$, 1335, $755 \mathrm{~cm}^{-1} ;{ }^{1} \mathrm{H}$ NMR (300 MHz, $\left.\mathrm{CDCl}_{3}\right): \delta 6.71(\mathrm{~s}, 1 \mathrm{H})$, 4.76-4.68 (m, 2H), $4.41(\mathrm{~d}, 1 \mathrm{H}, J=8.1), 3.67(\mathrm{~s}, 3 \mathrm{H}), 3.59(\mathrm{~s}$, $3 \mathrm{H}), 3.29(\mathrm{dt}, 1 \mathrm{H}, J=12.6,6.6), 2.99(\mathrm{dd}, 1 \mathrm{H}, J=12.3,7.8)$, 2.47 (dd, $1 \mathrm{H}, J=12.3,6.3), 2.30(\mathrm{dd}, 1 \mathrm{H}, J=12.3,6.9), 2.26$ (br s, 1H), $1.55-1.44(\mathrm{~m}, 1 \mathrm{H}), 1.47(\mathrm{~s}, 3 \mathrm{H}), 1.32(\mathrm{~s}, 3 \mathrm{H}) ;{ }^{13} \mathrm{C}$ NMR $\left(75 \mathrm{MHz} \mathrm{CDCl}_{3}\right): \delta 166.4,139.4,132.5,109.3,81.5,80.5$, 80.3, 72.4, 58.9, 51.9, 49.0, 39.0, 37.5, 26.3, 23.9; Found: C, $60.62 ; \mathrm{H}, 6.83 . \mathrm{C}_{15} \mathrm{H}_{22} \mathrm{O}_{6}$ requires: $\mathrm{C}, 60.82 ; \mathrm{H}, 6.80 \%$.

\section{4-Methoxy-2,2-dimethyl-7-vinylperhydroindeno[1,2-d][1,3]- dioxol-5-ol 22}

To a solution of unsaturated alcohol $19(130 \mathrm{mg}, 0.44 \mathrm{mmol})$ in absolute ethanol $(5 \mathrm{ml})$ was added $\mathrm{PtO}_{2}(2 \mathrm{mg})$ catalyst and the mixture was stirred under a hydrogen atmosphere for $1 \mathrm{~h}$ at $\mathrm{rt}$. The reaction mixture was filtered through a silica gel pad and the filtrate was concentrated to afford a mixture of saturated alcohols 20 (112 mg, 84\%) in an 85:15 ratio (from ${ }^{1} \mathrm{H}$ NMR) and was subjected to the next step as such. IR: $v_{\max } 3450,1725$, 1340, $750 \mathrm{~cm}^{-1}$; ${ }^{1} \mathrm{H}$ NMR (300 MHz, $\left.\mathrm{CDCl}_{3}\right): \delta 4.75-4.69(\mathrm{~m}$, $1 \mathrm{H}), 4.60(\mathrm{~d}, 1 \mathrm{H}, J=6), 3.69(\mathrm{~s}, 3 \mathrm{H}), 3.56(\mathrm{~s}, 3 \mathrm{H}), 3.64-3.54(\mathrm{~m}$, $2 \mathrm{H}), 2.82-2.65(\mathrm{~m}, 2 \mathrm{H}), 2.24-2.00(\mathrm{~m}, 2 \mathrm{H}), 1.82-1.60(\mathrm{~m}, 3 \mathrm{H})$, $1.46(\mathrm{~s}, 3 \mathrm{H}), 1.31(\mathrm{~s}, 3 \mathrm{H})$.

To a solution of $20(112 \mathrm{mg}, 0.37 \mathrm{mmol})$ in dry DCM $(5 \mathrm{ml})$ at $-78{ }^{\circ} \mathrm{C}, 1 \mathrm{M}$ DIBAL-H $(0.4 \mathrm{ml})$ was added under $\mathrm{N}_{2}$ and the mixture was stirred at $-78{ }^{\circ} \mathrm{C}$ for $30 \mathrm{~min}$. The reaction was quenched with saturated $\mathrm{NH}_{4} \mathrm{Cl}$ solution and diluted with DCM. The organic layer was separated and the aqueous layer was extracted with DCM. The combined organic extract was washed with water, brine, dried over $\mathrm{Na}_{2} \mathrm{SO}_{4}$ and then concentrated to afford the aldehyde 21 ( $\sim 90 \mathrm{mg})$. The crude aldehyde obtained was subjected to the next step as such. IR: $v_{\max } 3460$, 2710, 1720, 1370, 1200, $1045 \mathrm{~cm}^{-1}$; ${ }^{1} \mathrm{H}$ NMR $(300 \mathrm{MHz}$, $\left.\mathrm{CDCl}_{3}\right): \delta 9.67(\mathrm{~s}, 1 \mathrm{H}), 4.74(\mathrm{t}, 1 \mathrm{H}, J=5.7), 4.61(\mathrm{~d}, 1 \mathrm{H}$, $J=5.7), 3.65-3.54(\mathrm{~m}, 1 \mathrm{H}), 3.57(\mathrm{~s}, 3 \mathrm{H}), 3.02-2.94(\mathrm{~m}, 1 \mathrm{H})$, 2.77-2.62 (m, 2H), 2.20-1.48 (series of $\mathrm{m}, 5 \mathrm{H}), 1.47(\mathrm{~s}, 3 \mathrm{H})$, $1.32(\mathrm{~s}, 3 \mathrm{H})$

To a suspension of methyltriphenylphosphonium iodide (270 $\mathrm{mg}, 0.66 \mathrm{mmol})$ in dry THF $(3 \mathrm{ml})$ was added $1.6 \mathrm{M} n$-BuLi $(0.4$ $\mathrm{ml})$ under nitrogen atmosphere. and the mixture was stirred for $5 \mathrm{~min}$ at $\mathrm{rt}$. To the canary yellow ylide that formed was added $\mathbf{2 1}$ $(90 \mathrm{mg}, 0.33 \mathrm{mmol})$ in THF $(2 \mathrm{ml})$ and the reaction mixture stirred further for $15 \mathrm{~min}$ and quenched with water. The organic layer was separated and the aqueous layer was extracted with ether. The combined organic layer was washed with water, brine, dried over $\mathrm{Na}_{2} \mathrm{SO}_{4}$ and concentrated. The residue was purified by silica gel column chromatography (elution with $20 \%$ EtOAc-hexane) and crystallization yielded the pure major isomer $22(48 \mathrm{mg})$ as a white crystalline solid in $48 \%$ overall yield. $\mathrm{Mp}: 88^{\circ} \mathrm{C}$; IR (KBr): $v_{\max } 3450,1640,1370,1265,1205,900$ $\mathrm{cm}^{-1} ;{ }^{1} \mathrm{H}$ NMR $\left(300 \mathrm{MHz}, \mathrm{CDCl}_{3}\right): \delta 5.76(\mathrm{ddd}, 1 \mathrm{H}, J=16.8$, $10.8,6.3), 5.03-4.96(\mathrm{~m}, 2 \mathrm{H}), 4.70(\mathrm{t}, 1 \mathrm{H}, J=5.4), 4.61(\mathrm{~d}, 1 \mathrm{H}$, $J=6), 3.68-3.62(\mathrm{~m}, 1 \mathrm{H}), 3.55(\mathrm{~s}, 3 \mathrm{H}), 2.72(\mathrm{t}, 1 \mathrm{H}, J=11.1)$, $2.59-2.52(\mathrm{~m}, 2 \mathrm{H}), 2.07(\mathrm{dd}, 1 \mathrm{H}, J=10.8,5.4), 1.87(\mathrm{td}, 1 \mathrm{H}$, $J=12.9,3), 1.69(\mathrm{dd}, 1 \mathrm{H}, J=14.1,5.1), 1.65-1.56(\mathrm{~m}, 2 \mathrm{H}), 1.45$ $(\mathrm{s}, 3 \mathrm{H}), 1.31(\mathrm{~s}, 3 \mathrm{H}) ;{ }^{13} \mathrm{C}$ NMR $\left(100 \mathrm{MHz}, \mathrm{CDCl}_{3}\right): \delta 140.4$, 113.6, 108.8, 82.3, 81.7, 79.2, 73.2, 58.7, 49.7, 39.7, 38.0, 32.3, 31.5, 25.9, 23.6; Found: $\mathrm{C}, 66.83 ; \mathrm{H}, 9.04 . \mathrm{C}_{15} \mathrm{H}_{24} \mathrm{O}_{4}$ requires: C, $67.14 ; \mathrm{H}, 9.01 \%$.

\section{4-Methoxy-2,2-dimethyl-7-vinylperhydroindeno[1,2-d][1,3]- dioxol-5-yl acetate 23}

To a solution of alcohol 22 (40 $\mathrm{mg}, 0.15 \mathrm{mmol})$ in dry pyridine $(2 \mathrm{ml})$, cooled in an ice-bath, were added a catalytic amount of DMAP and $0.5 \mathrm{ml}$ of $\mathrm{Ac}_{2} \mathrm{O}$ and the mixture was stirred at $\mathrm{rt}$ for $2 \mathrm{~h}$. The reaction was quenched with crushed ice and extracted with diethyl ether. The organic layer was washed with dil. $\mathrm{HCl}$, water, brine, and dried over $\mathrm{Na}_{2} \mathrm{SO}_{4}$. Evaporation of the solvent and purification through a silica gel column (elution with $10 \%$ EtOAc-hexane) furnished 23 (40 mg) in $86 \%$ yield. IR(neat): $v_{\max } 1725,1370,1240,1020 \mathrm{~cm}^{-1} ;{ }^{1} \mathrm{H}$ NMR $\left(500 \mathrm{MHz}, \mathrm{CDCl}_{3}\right)$ : $\delta 5.71$ (ddd, $1 \mathrm{H}, J=17,10,6.5), 4.98(\mathrm{~d}, 1 \mathrm{H}, J=4.2), 4.96$ (s, $1 \mathrm{H}), 4.83-4.78(\mathrm{~m}, 1 \mathrm{H}), 4.69(\mathrm{t}, 1 \mathrm{H}, J=5.5), 4.55(\mathrm{~d}, 1 \mathrm{H}$, $J=5.6), 3.47(\mathrm{~s}, 3 \mathrm{H}), 2.85(\mathrm{t}, 1 \mathrm{H}, J=10.5), 2.61-2.50(\mathrm{~m}, 2 \mathrm{H})$, $2.07(\mathrm{~s}, 3 \mathrm{H}), 2.06(\mathrm{dd}, 1 \mathrm{H}, J=10.8,3.7), 1.92(\mathrm{td}, 1 \mathrm{H}, J=8.6$, 4), $1.70(\mathrm{dd}, 1 \mathrm{H}, J=14.1,6.4), 1.52(\mathrm{dt}, 1 \mathrm{H}, J=13.5,5.5), 1.44$ $(\mathrm{s}, 3 \mathrm{H}), 1.40(\mathrm{q}, 1 \mathrm{H}, J=12.1), 1.30(\mathrm{~s}, 3 \mathrm{H}) ;{ }^{13} \mathrm{C}$ NMR $(125$ $\left.\mathrm{MHz}, \mathrm{CDCl}_{3}\right): \delta 170.1,139.9,113.9,108.9,82.6,79.1,78.4$, 76.3, 59.5, 50.5, 39.2, 37.7, 31.4, 30.0, 25.9, 23.6, 21.3; Found: C, 65.84; $\mathrm{H}, 8.48 . \mathrm{C}_{17} \mathrm{H}_{26} \mathrm{O}_{5}$ requires: $\mathrm{C}, 65.78 ; \mathrm{H}, 8.44 \%$.

\section{Methyl 2-(3-methoxy-4-acetoxy-2-methoxycarbonyl-6-vinyl- cyclohexyl)acetate 24}

Acetonide 23 (36 mg, $0.116 \mathrm{mmol}$ ) was dissolved in $2 \mathrm{ml}$ of $30 \%$ aqueous trifluoroacetic acid and stirred at $\mathrm{rt}$ for $1 \mathrm{~h}$. The volatile material was removed under vacuum and the residue in $3 \mathrm{ml}$ of $10 \%$ aqueous THF was treated with $\mathrm{NaIO}_{4}(30 \mathrm{mg}, 0.14$ $\mathrm{mmol}$ ) at ice temperature. The solution was stirred for $15 \mathrm{~min}$, diluted with water and extracted with diethyl ether. The organic layer was washed, dried and concentrated. The crude dialdehyde obtained was dissolved in acetone $(2 \mathrm{ml})$ and treated with 4-5 drops of $0.7 \mathrm{M}$ Jones reagent. The mixture was stirred for 15 min, diluted with water and extracted with diethylether. The organic layer was washed, dried and concentrated to afford the crude diacid. The diacid in dry ether $(2 \mathrm{ml})$ was treated with excess of diazomethane in ether and left for $10 \mathrm{~min}$ at ice temperature. The excess diazomethane was quenched with $\mathrm{AcOH}$ and the volatile materials were removed under reduced pressure. The residue was purified by silica gel column chromatography (elution with 10\% EtOAc-hexane) to furnish the diester $\mathbf{2 4}$ ( $8 \mathrm{mg}$ ) in $21 \%$ overall yield, from 23 . IR (neat): $v_{\max } 2960,1730$, 1440, 1370, 1240, $1090 \mathrm{~cm}^{-1}$; ${ }^{1} \mathrm{H}$ NMR (300 MHz, $\left.\mathrm{CDCl}_{3}\right)$ : $\delta 5.73(\mathrm{ddd}, 1 \mathrm{H}, J=17.1,10.5,4.8), 5.03(\mathrm{~m}, 2 \mathrm{H}), 4.78$ (ddd, $1 \mathrm{H}, J=14.4,11.7,5.1), 3.67(\mathrm{~s}, 3 \mathrm{H}), 3.65(\mathrm{~m}, 1 \mathrm{H}), 3.62(\mathrm{~s}, 3 \mathrm{H})$, $3.45(\mathrm{~s}, 3 \mathrm{H}), 2.81(\mathrm{~m}, 1 \mathrm{H}), 2.67(\mathrm{dd}, 1 \mathrm{H}, J=11.4,4.2), 2.45(\mathrm{~m}$, $2 \mathrm{H}), 2.10(\mathrm{~s}, 3 \mathrm{H}), 2.07(\mathrm{~m}, 1 \mathrm{H}), 1.25(\mathrm{~m}, 2 \mathrm{H}) ;{ }^{13} \mathrm{C}$ NMR $(75$ $\left.\mathrm{MHz}, \mathrm{CDCl}_{3}\right): \delta 173.0,172.7,170.3,138.3,115.9,78.3,76.6$, $60.9,52.0,51.7,51.3,41.1,36.1,29.2,29.1,21.3$. The spectral data for $\mathbf{2 4}$ were found to be identical through direct comparison with the same compound reported by Fraser-Reid et al. ${ }^{3 f}$

\section{Acknowledgements}

We thank Professor B. Fraser-Reid for providing the spectral data on $\mathbf{2 4}$ for comparison purposes. D. S. R. thanks UGC, New Delhi, for a research fellowship. This research was supported by the Jawaharlal Nehru Center for Advanced Scientific Research, Bangalore.

\section{References}

1 Isolation, see: (a) J. M. Muller, E. Schlittler and H. J. Bein, Experientia, 1952, 8, 338; (b) A. Chatterjee, Fortschr. Chem. Org. Naturst., 1953, 10, 390; (c) A. Chatterjee, S. C. Pakrashi and G. Werner, Fortschr. Chem. Org. Naturst., 1956, 13, 346.

2 For structure and stereochemistry determination, see: $(a)$ L. Dorfman, A. Furlenmeier, C. F. Huebner, R. Lucas, H. B. MacPhillamy, J. M. Mueller, E. Schlittler, R. Schwyzer and A. F. St. Andre, Helv. Chim. Acta, 1954, 37, 59; (b) E. E. van Tamelen and P. D. Hance, J. Am. Chem. Soc., 1955, 77, 4692; (c) E. Wenkert and L. H. Liu, Experientia, 1955, 11, 302; (d) P. A. Diassi, F. Weisenborn, C. M. Dylion and O. Wintersteiner, J. Am. Chem. Soc., 1955, 77, 4687.

3 For the total synthesis of reserpine accomplished so far, see: $(a)$ R. B. Woodward, F. E. Bader, H. Bickel, A. J. Frey and R. W. Kierstead, J. Am. Chem. Soc., 1956, 78, 2023; R. B. Woodward, F. E. Bader, H. Bickel, A. J. Frey and R. W. Kierstead, J. Am. Chem. Soc., 1956, 78, 2657; R. B. Woodward, F. E. Bader, H. Bickel, A. J. Frey and 
R. W. Kierstead, Tetrahedron, 1958, 2, 1; (b) B. A. Pearlman, J. Am. Chem. Soc., 1979, 101, 6404; (c) P. A. Wender, J. M. Schaus and A. W. White, J. Am. Chem. Soc., 1980, 102, 6159; (d) S. F. Martin, S. Grzejszczak, H. Rueger and S. A. Williamson, J. Am. Chem. Soc., 1987, 109, 6124; (e) G. Stork, Pure Appl. Chem., 1989, 61, 439; $(f)$ A. M. Gomez, J. C. Lopez and B. Fraser-Reid, J. Org. Chem., 1994, 59, 4048; A. M. Gomez, J. C. Lopez and B. Fraser-Reid, J. Org Chem., 1995, 60, 3859; $(g)$ C.-S. Chu, C.-C. Liao and P. D. Rao, Chem. Commun., 1996, 1537; (h) S. Hanessian, J. Pan, A. Carnell, H. Bouchard and L. Lesage, J. Org. Chem., 1997, 62, 465.

4 For representative examples of synthetic efforts towards reserpine see: (a) S. Takano, F. Ito and K. Ogasawara, Heterocycles, 1980, 14, 453; (b) C. Szantay, G. Blasko, K. Honty, E. Baitz-Gacs and L. Toke, Liebigs Ann. Chem., 1983, 1269; (c) E. Wenkert, Heterocycles, 1984, 21, 325; (d) M. E. Jung and L. A. Light, J. Am. Chem. Soc., 1984, 106, 7614; (e) R. P. Polniaszek and R. V. Stevens, J. Org. Chem., 1986, 51,
3023; $(f)$ S. Chao, F. A. Kunng, J. M. Gu, H. L. Ammon and P. S. Mariano, J. Org. Chem., 1984, 49, 2708; $(g)$ M. Toyota, T. Wada, M. Matsuura and K. Fukumoto, Synlett, 1995, 761; $(h)$ G. Mehta and D. S. Reddy, Synlett, 1997, 612.

5 Some portions of this work have been reported previously, see: G. Mehta and D. S. Reddy, J. Chem. Soc., Perkin Trans. 1, 1998, 2125. 6 C. A. Peri, Gazz. Chim. Ital., 1955, 85, 1118.

7 H. S. P. Rao, S. P. Senthilkumar, D. S. Reddy and G. Mehta, Ind. J. Chem., 1999, 38B, 260.

8 (a) A. J. Pearson, Y.-S. Chen, S.-Y. Hsu and T. Ray, Tetrahedron Lett., 1958, 25, 1235; (b) E. J. Corey and G. W. J. Fleet, Tetrahedron Lett., 1973, 4499; (c) F. C. Whitmore and G. W. Pedlow, J. Am. Chem. Soc., 1941, 63, 758; (d) M. A. Umbriet and K. B. Sharpless, J. Am. Chem. Soc., 1977, 99, 5526; (e) N. Chidambaram and S. Chandrasekaran, J. Org. Chem., 1987, 52, 5408.

9 J.-L. Luche, J. Am. Chem. Soc., 1978, 100, 2226. 